\title{
Accumulation of Peptides by Mycobacillin-negative Mutants of Bacillus subtilis $\mathbf{B}_{3}$
}

\author{
By SEKHAR MAJUMDER, SUBRATA K. GHOSH, \\ NISHIT K. MUKHOPADHYAY AND SUSIL K. BOSE* \\ Department of Biochemistry, University College of Science, 35 Ballygunge Circular Road, \\ Calcutta 700 019, India
}

(Received 29 March 1984; revised 3 August 1984)

\begin{abstract}
Thirteen mycobacillin-negative $\left(\mathrm{My}^{-}\right)$mutants of Bacillus subtilis $\mathbf{B}_{3}$ were isolated from an auxotrophically tagged mycobacillin producer organism. The wild-type producer, three feeble producers and three strictly $\mathrm{My}^{-}$mutants did not accumulate any ninhydrin-positive peptide in the culture medium while the remaining seven $\mathrm{My}^{-}$mutants did accumulate ten such peptides whose amino acid composition indicated that there might be only three different peptides. The $\mathrm{N}$-terminal and $\mathrm{C}$-terminal amino acid residues implicated one of these peptides as a pentapeptide intermediate in mycobacillin synthesis; this was further confirmed by its molecular weight and sequence. Studies on cell-free synthesis showed that only the enzyme system from the wild-type strain synthesized mycobacillin while the defective ones from all the $\mathrm{My}^{-}$mutants synthesized one and the same pentapeptide as found in the culture broth of some of the mutants. Further studies in which the enzymes responsible for mycobacillin synthesis by cell-free extracts were separated into three fractions, A, B and C, showed that seven of the mutants were defective in fraction $B$ whereas the three other mutants had defects in both fractions B and C. Thus the pentapeptide Pro $\rightarrow A s p \rightarrow G l u \rightarrow T y r \rightarrow A s p$ appears to be implicated in mycobacillin biosynthesis.
\end{abstract}

\section{INTRODUCTION}

The use of 'blocked' mutants, as developed by Beadle \& Tatum (1941) has proved very effective in the study of intermediary metabolism. The technique has also been extended to the biosynthesis of antibiotics, e.g. penicillin (Edwards \& Holt, 1974), cephalosporin C (Queener et al., 1974) and tetracycline (McCormick et al., 1968). Loder \& Abraham $(1971 a, b)$ isolated and identified the tripeptide L- $\alpha$-aminoadipyl-L-cysteinyl-D-valine (ACV) from cell-free extracts of Cephalosporium acremonium. Lemke \& Nash (1972) isolated from blocked mutants of $C$. acremonium ACV-like compounds implicated as intermediates in the elaboration of penicillin $\mathrm{N}$ and cephalosporin C. Fujisawa et al. (1973) isolated a mutant of C. acremonium blocked in the conversion of deacetylcephalosporin C (DCPC) to cephalosporin C. McCormick et al. (1958) isolated mutants of a chlorotetracycline producer organism that were blocked in the reduction of dehydrochlorotetracycline to chlorotetracycline, and therefore accumulated dehydrochlorotetracycline. The biosynthesis of mycobacillin, a cyclic antifungal antibiotic produced by Bacillus subtilis $\mathrm{B}_{3}$ (Majumder \& Bose, 1958), does not involve an RNA template: activation of the constituent amino acids occurs as a result of ATP- $\mathrm{P}_{i}$ exchange, proline being the initiating amino acid in the synthesis (Sengupta \& Bose, 1974). An amino acid deprivation technique was developed for the isolation of possible intermediates in mycobacillin synthesis (Sengupta \& Bose, 1972); however, these intermediates, in the presence of complementary amino acids, were not incorporated into mycobacillin (Sengupta \& Bose, 1982).

Abbretiation: NTG, $N$-methyl- $N^{\prime}$-nitro- $N$-nitrosoguanidine. 
The present communication describes the isolation of some mycobacillin-negative mutants from an auxotrophically tagged mutant of the producer $B$. subtilis $\mathrm{B}_{3}$ and the use of these blocked mutants in whole-cell fermentation and cell-free in vitro synthesis, both to isolate and characterize some peptides that might be involved in mycobacillin biosynthesis, and to locate the enzyme defect in the three fractions (Ghosh et al., 1983) of the mycobacillin synthetase complex.

\section{METHODS}

Organisms, cultural conditions and media. Bacillus subtilis $\mathbf{B}_{3}$, originally isolated in this laboratory (Majumder \& Bose, 1958), produces $0.37 \mathrm{mg}$ mycobacillin per ml of nutrient broth; recovery by the standard process is $65 \%$ (Majumder \& Bose, 1960a). This organism was used to produce auxotrophic mutants which were subsequently used to isolate mycobacillin-negative $\left(\mathrm{My}^{-}\right)$mutants.

For the isolation of auxotrophic as well as $\mathrm{My}^{-}$mutants, we used a complete medium containing (per litre) glucose, $10 \mathrm{~g}$; peptone, $5 \mathrm{~g}$ and beef extract, $3 \mathrm{~g}\left(\mathrm{pH} 7 \cdot 0\right.$ ); and a minimal medium containing (per litre) $\left(\mathrm{NH}_{4}\right)_{2} \mathrm{SO}_{4}$, $20 \mathrm{~g} ; \mathrm{K}_{2} \mathrm{HPO}_{4}, 14 \mathrm{~g} ; \mathrm{KH}_{2} \mathrm{PO}_{4}, 6 \mathrm{~g}$; sodium citrate, $1 \mathrm{~g} ; \mathrm{MgSO}_{4} .7 \mathrm{H}_{2} \mathrm{O}, 0 \cdot 2 \mathrm{~g}$ and glucose, $5 \mathrm{~g}$ (pH 7.0). For isolation of peptide intermediates by whole-cell fermentation, a synthetic medium was used containing (per litre) glucose, $10 \mathrm{~g}$; glutamic acid, $5 \mathrm{~g} ; \mathrm{KH}_{2} \mathrm{PO}_{4}, 1 \mathrm{~g} ; \mathrm{MgSO}_{4} .7 \mathrm{H}_{2} \mathrm{O}, 1 \mathrm{~g} ; \mathrm{MnSO}_{4} .4 \mathrm{H}_{2} \mathrm{O}, 0.01 \mathrm{~g}$ and $\mathrm{FeSO}_{4} .7 \mathrm{H}_{2} \mathrm{O}$, $0.01 \mathrm{~g}(\mathrm{pH} \mathrm{7.2)}$.

Isolation and characterization of auxotrophic mutants. The isolation was based on the method of Adelberg et al. (1965). NTG ( $N$-methyl- $N$-nitro- $N$-nitrosoguanidine) $\left(100 \mu \mathrm{g} \mathrm{ml}^{-1}\right)$ was added to a shaken culture of the organism at mid-exponential phase. The treated culture was incubated for $30 \mathrm{~min}$ in Tris/maleate buffer $(0.05 \mathrm{M})$ at $\mathrm{pH} 6.0$ and then transferred to complete medium for $24 \mathrm{~h}$ at $32^{\circ} \mathrm{C}$. Potential auxotrophs were detected by replica plating on minimal medium and characterized by the methods of Lederberg (1950) and Holliday (1956).

Isolation of mycobacillin-negative $\left(\mathrm{My}^{-}\right)$mutants. Two methods were used.

(1) One mutant arbitrarily selected from among the auxotrophs and designated A-1' was treated with NTG as described above and then plated on complete medium. The plates containing the established colonies were then flooded with agar seeded with the mycobacillin-sensitive fungus Aspergillus niger $\mathrm{G}_{3} \mathrm{Br}$ to detect non-producer strains according to the method of Banerjee \& Bose (1964). Two thousand colonies were screened and $\mathrm{My}^{-}$ mutants thus identified were then transferred to nutrient broth containing $250 \mu \mathrm{g}$ mycobacillin $\mathrm{ml}^{-1}$ and incubated for $24 \mathrm{~h}$ at $30^{\circ} \mathrm{C}$. The blocked mutants, now free from $A$. niger $\mathrm{G}_{3} \mathrm{Br}$, were maintained on nutrient agar slopes.

(2) This method was based on one developed by Raetz (1975) for isolating mutants blocked in membrane lipid synthesis, and further modified by Mukherjee \& Paulus (1977) for the isolation of gramicidin-negative mutants. The auxotrophic mutant A-1' was treated with NTG as before and then plated on complete medium. After incubation for $24 \mathrm{~h}$, plates containing 50-80 colonies were imprinted upon sterile disks of Whatman no. 42 filter paper. The paper so imprinted was soaked with mycobacillin amino acid mixture, containing $2 \mathrm{mM}$ each of L-proline, DLaspartic acid, L-tyrosine, L-serine, L-leucine, L-glutamic acid, $0.15 \mu \mathrm{Ci} \mathrm{L}-\left[3-{ }^{-14} \mathrm{C}\right]$ alanine (sp. act. $60 \mathrm{Ci} \mathrm{mol}^{-1}$; $\left.2 \cdot 2 \mathrm{TBq} \mathrm{mol}^{-1}\right)$ and chloramphenicol $\left(100 \mu \mathrm{g} \mathrm{ml}^{-1}\right)$ and incubated at $27^{\circ} \mathrm{C}$ for $2 \mathrm{~h}$. Then autoradiography was done using Indu-medical X-ray film and the colonies that were stained by Coomassie blue but produced no exposure of the film were isolated from the original master plate. One thousand colonies were screened by this technique.

Sporulating ability of the $M y^{-}$mutants. This was determined by estimating at different time intervals the number of spores per $\mathrm{ml}$ of culture, using a double Neubauer chamber under a phase-contrast microscope at $400 \times$ magnification.

Confirmation of the $\mathrm{My}^{-}$character of the isolated mutants. This was done by a cross-streak method against the sensitive organism $A$. niger $\mathrm{G}_{3} \mathrm{Br}$ and also by silica gel thin-layer chromatography. For thin-layer chromatographic analysis, mutants were inoculated into $100 \mathrm{ml}$ synthetic medium and incubated for $6 \mathrm{~d}$ at $27^{\circ} \mathrm{C}$ without shaking for optimum synthesis (Majumder \& Bose, 1960b). The culture fluid was extracted three times with chloroform/1butanol $(1: 4, \mathrm{v} / \mathrm{v})$. The extract was evaporated under reduced pressure and the residue dissolved in a minimal volume of ethanol and then processed further by the method of Majumder \& Bose (1960a). The residue was finally characterized by silica gel thin-layer chromatography using 1 -propanol/ammonia $(2: 1, \mathrm{v} / \mathrm{v})$ as the developing solvent (Goswami \& Bose, 1982).

The $\mathrm{My}^{-}$character was finally confirmed by screening for cell-free synthesis by the method of Sengupta \& Bose (1971) as modified by Mukhopadhyay et al. (1984). Cells ( $2.5 \mathrm{~g}$ wet wt) of wild-type and $\mathrm{My}^{-}$strains, collected from 1 litre of nutrient broth after $15-16 \mathrm{~h}$ incubation at $30^{\circ} \mathrm{C}$, were suspended in 4 vols $50 \mathrm{mM}$-Tris/ $\mathrm{HCl}$ buffer at $\mathrm{pH} 7.4$ containing $2 \mathrm{~mm}-\mathrm{EDTA}, 10 \mathrm{mM}-\mathrm{DTT}, 10 \mathrm{~mm}-\mathrm{MgCl}_{2}$ and $1 \mathrm{~mm}-\mathrm{PMSF}$ (phenylmethylsulphonyl fluoride) in a glass tube. The tube was immersed in an ice-salt bath and the suspension sonicated for two $30 \mathrm{~s}$ periods at $100 \mathrm{~W}$ and $20 \mathrm{kHz}$ in an MSE ultrasonicator. The suspension was cooled for 3 min between bursts to maintain a 
temperature below $5{ }^{\circ} \mathrm{C}$. The sonicate was centrifuged at $20000 \mathrm{~g}$ for $30 \mathrm{~min}$ at $0-2{ }^{\circ} \mathrm{C}$ and the supernatant used as enzyme source. The protein concentration of the supernatant was measured by the Lowry method with bovine serum albumin as the standard. The incubation mixture contained the following in a total volume of $2 \mathrm{ml}: 5 \mu \mathrm{Ci}$ U-1+C-labelled Chlorella protein hydrolysate (42 mCi per mg atom C), $5 \mu \mathrm{M}$-A TP, $5 \mu \mathrm{M}$-phosphoenolpyruvate, $20 \mu \mathrm{g}$ pyruvate kinase, $10 \mu \mathrm{M}-\mathrm{MgCl}_{2}, 100-\mu \mathrm{M}-\mathrm{Tris} / \mathrm{HCl}$ buffer ( $\mathrm{pH} 7 \cdot 4$ ), $100 \mu \mathrm{g}$ chloramphenicol, $8 \mathrm{mg}$ enzyme protein. $4 \mu \mathrm{M}$-D-aspartic acid, $1 \mu \mathrm{M}$-L-aspartic acid, $2 \mu \mathrm{M}$-D-glutamic acid, $1 \mu \mathrm{M}$-L-glutamic acid, $2 \mu \mathrm{M}$-tyrosine and $1 \mu \mathrm{M}$ each of L-leucine, L-alanine, $\mathrm{L}$-proline and $\mathrm{L}$-serine. The mixture was incubated at $30 \pm 1{ }^{\circ} \mathrm{C}$ for $120 \mathrm{~min}$ and the reaction terminated by the addition of 3 vols 1 -butanol. Unlabelled mycobacillin $(2 \mathrm{mg})$ was added as carrier and mycobacillin was isolated from the butanol extract as described by Majumder \& Bose (1960a). The radioactive count was taken of the total final ethanolic solution of the antibiotic after its recovery from the butanol extract without allowing it to crystallize.

Isolation of peptides from $\mathrm{My}^{-}$mutants. The $\mathrm{My}^{-}$mutants were incubated without shaking for $6 \mathrm{~d}$ at $27^{\circ} \mathrm{C}$. The culture fluid was extracted three times with chloroform/1-butanol $(1: 4, \mathrm{v} / \mathrm{v})$, the solvent layer dried under reduced pressure and the residue dissolved in a minimal volume of ethanol containing $10 \%(\mathrm{v} / \mathrm{v}) 10 \mathrm{M}-\mathrm{HCl}$. After centrifugation the dissolved residue was then chromatographed in two dimensions in solvent systems (i) phenol/water $(3: 1, w / w)$ and (ii) 1-butanol/acetic acid/water $(4: 1: 1$, by vol.) and sprayed with a solution of $0.2 \%$ ninhydrin in 1-butanol. Ninhydrin-positive spots, other than those representing residual amino acids added initially to the fermentation medium, were eluted from an unsprayed chromatogram and rechromatographed in the same two solvent systems and also in $70 \%(\mathrm{v} / \mathrm{v})$ ethanol, to test their homogeneity. Each of the spots obtained in the chromatogram was then eluted with $70 \%(\mathrm{v} / \mathrm{v})$ ethanol.

Identification and determination of the molar proportion of the constituent amino acids. The ninhydrin-positive spots, other than those for aspartic acid (auxotrophic marker of $\mathrm{A}-\mathrm{1}^{\prime}$ ) and glutamic acid used in the fermentation medium were eluted from an unsprayed chromatogram and hydrolysed with $10 \mathrm{M}-\mathrm{HCl}$ in a sealed tube at $105^{\circ} \mathrm{C}$ for $18 \mathrm{~h}$. The hydrolysate was dried in vacuo and the acid removed completely. The residue was then dissolved in $10 \%(\mathrm{v} / \mathrm{v}) 2$-propanol and chromatographed in two dimensions in solvent systems (i) and (ii) as above. The amino acids appearing in the chromatogram were identified and their molar proportions were determined by a ninhydrin method (Giri et al., 1952).

Determination of the $\mathrm{C}$ - and $\mathrm{N}$-terminal amino acid of the peptides. The $\mathrm{C}$-terminal amino acid of each peptide isolated from the chromatogram was determined by the method of Akabori et al. (1956). Each peptide was incubated at $60{ }^{\circ} \mathrm{C}$ for $2 \mathrm{~h}$ with two drops of anhydrous hydrazine in a sealed tube. The tubes were opened and excess hydrazine was removed in a vacuum desiccator over $\mathrm{H}_{2} \mathrm{SO}_{4}$. The dried mass was then dissolved in water and shaken overnight with the carboxylic resin Amberlite IRC-50 $\left(\mathrm{H}^{+}\right.$form). After removal of the residue the supernatant $(2 \mathrm{ml})$ was shaken with benzaldehyde $(0.2 \mathrm{ml})$ and pyridine $(0.1 \mathrm{ml})$ overnight in a stoppered cylinder. The aqueous layer was then dried and chromatographed in two dimensions in solvent systems (i) and (ii) described above. Amino acids were identified by comparison with authentic samples.

The N-terminal amino acid of each of the peptides was determined by the fluorodinitrobenzene method (Sanger, 1945). Each peptide was dissolved in $1 \mathrm{ml} \mathrm{0.1} \mathrm{M}-\mathrm{NaHCO}_{3}$ and $0.1 \mathrm{ml}$ fluorodinitrobenzene was added. The DNP-peptide was hydrolysed with $5 \cdot 7 \mathrm{M}-\mathrm{HCl}$ for $3 \mathrm{~h}$ at $110^{\circ} \mathrm{C}$ and extracted with ether. The ether layer was dried and the residue subjected to two-dimensional paper chromatography in the dark in the solvent systems chloroform/benzyl alcohol/acetic acid $(70: 30: 3$, by vol.) and benzene/pyridine/acetic acid $(40: 1: 1$, by vol.). Each DNP-amino acid was identified by comparison with an authentic sample.

Determination of molecular weight. This was done by the method of Carnegie (1965). Columns of Sephadex G-25 (fine beads, $10 \mathrm{~g}, 1.1 \mathrm{~cm}$ diameter) were used with phenol/acetic acid/water $(1: 1: 1, \mathrm{w} / \mathrm{v} / \mathrm{v})$ as solvent. A series of peptides of known molecular weight were used for calibration. Their migration rates, relative to that of cytochrome $c$ were as follows: $\beta$-alanine (mol. wt 89-1), 0.52; L-Trp-L-Gly (mol. wt 261·3), 0.53; leucine enkephalin (mol. wt 555.6), 0.60: L-Trp-L-Ala-Gly-Gly-L-Asp-L-Ala-L-Ser-Gly-L-Glu (mol. wt 848.8), 0.76; $\beta$-Asp ${ }^{1}-\mathrm{Val}^{5}$ angiotensin II (mol. wt 1032), 0.81; $\alpha$-melanotrophin (mol. wt 1725), 0.92; glucagon (mol. wt 3485), 0.95 ; insulin (mol. wt 5733), 0.99.

Attempt to isolate intermediate-peptides from cell-free synthesis by wild-type and mutant strains. Cell-free extracts of the strains were prepared and treated with $\left(\mathrm{NH}_{4}\right)_{2} \mathrm{SO}_{4}$. The precipitate collected between $30 \%$ and $55 \%$ saturation (Ghosh et al., 1983) was dissolved in buffer $(50 \mathrm{~mm}$-Tris/ $\mathrm{HCl} \mathrm{pH} 7 \cdot 2$, containing $0.25 \mathrm{~mm}-\mathrm{EDTA}, 10 \mathrm{~mm}-$ $\mathrm{MgCl}_{2}$ and $1 \mathrm{~mm}$-DTT) and dialysed for $10 \mathrm{~h}$ against 2 litres of the same buffer, and used as a source of the enzyme. The incubation mixture $(2 \mathrm{ml})$ used for the synthesis of peptides contained $5 \mathrm{mg}$ enzyme, $100 \mu \mathrm{mol} \mathrm{Tris} / \mathrm{HCl}$ buffer $\mathrm{pH} 7 \cdot 2,10 \mu \mathrm{mol}$ ATP, $5 \mu \mathrm{mol}$ DTT and mixtures of a full complement of both mycobacillin and non-mycobacillin amino acids ( $10 \mu \mathrm{mol}$ each) as present in the peptides isolated from $\mathrm{My}^{-}$mutants. The mixture was incubated for $30 \mathrm{~min}$ and the reaction was terminated with 4 vols chloroform/1-butanol $(1: 4, \mathrm{v} / \mathrm{v})$. Each set of 50 tubes was extracted three times with chloroform/l-butanol and centrifuged. The solvent layer was then removed under reduced pressure and the residue chromatographed as described previously.

Mycobacillin synthesis by mixtures of the three fractions of wild-type and mutant mycobacillin synthetase. The en- 
zyme systems from wild-type and mutant cells were processed according to the method of Ghosh et al. (1983) to give three fractions, A, B and C. The combined fractions from wild-type bacteria synthesized mycobacillin from its constituent amino acids. Fractions $\mathrm{A}, \mathrm{B}$ and $\mathrm{C}$ of mycobacillin synthetase from wild type and mutant bacteria were then mixed in various combinations for measurement of mycobacillin synthesis by the radioactive tracer technique described above.

Determination of the amino acid sequence of the peptide that accumulated in fermentation broths and in the cell-free system. This was done by the method of Edman (1960). The peptide sample (1 mg) was dissolved in $4 \mathrm{ml} .50 \%(\mathrm{w} / \mathrm{v})$ aqueous dioxan, and the solution was brought to $\mathrm{pH} 8 \cdot 7-9 \cdot 0$ with $0.01 \mathrm{M}-\mathrm{NaOH}$ and stirred for $1.5 \mathrm{~h}$ at $40^{\circ} \mathrm{C}$ with $0.1 \mathrm{ml}$ phenylisothiocyanate, keeping the $\mathrm{pH}$ constant. The reaction mixture was then extracted six or seven times with benzene and the aqueous solution concentrated in vacuo over $\mathrm{NaOH}$. After cleavage with $30 \mu \mathrm{l}$ trifluoroacetic acid for $20 \mathrm{~min}$ at $40^{\circ} \mathrm{C}$, the residual peptide was precipitated with $0.7 \mathrm{ml}$ ethylene chloride and washed with $0.7 \mathrm{ml}$ ethylene chloride. The precipitate was dried overnight in vacuo over $\mathrm{P}_{2} \mathrm{O}_{5}$ and used for the next degradation cycle. The intermediate thiazolinone in the ethylene chloride phase was dried and converted to the corresponding thiohydantoin by treatment with $0.4 \mathrm{ml} 1 \mathrm{M}-\mathrm{HCl}$ at $80^{\circ} \mathrm{C}$ for $10 \mathrm{~min}$ by the method of Edman \& Begg (1967). The thiohydantoin derivative was extracted three or four times with $0.4-0.8 \mathrm{ml}$ ethyl acetate. The extract was then dried and dissolved in an appropriate amount of ethyl acetate. It was then chromatographed and spots on the chromatograms were located by UV illumination (Edman \& Sjoquist, 1956) and by the iodine azide reaction (Sjoquist, 1953). The yields of amino acid phenylthiohydantoins were determined on the basis of their absorbance at $269 \mathrm{~nm}$ in the organic and water phase before chromatography.

\section{RESULTS}

Effect of auxotrophic mutations on mycobacillin production. Five auxotrophic mutant derivatives of wild-type Bacillus subtilis $\mathrm{B}_{3}$ were obtained. Mutants A-1' and A-3 required aspartic acid, A-4 and A-5 proline and A-1 arginine. All these mutants retained their $\mathrm{My}^{+}$(mycobacillin-producing) and $\mathrm{Spo}^{+}$(sporogenous) character (Table 1).

Characterization of $\mathrm{My}^{-}$strains. Two thousand colonies were screened by method (1) (see Methods) and $12 \mathrm{My}^{-}$mutants were isolated (strains $\mathrm{N}-2^{\prime} 01$ to $\mathrm{N}-10$ listed in Table 1). Only one $\mathrm{My}^{-}$mutant (N-1111) was isolated after screening 1000 colonies by method (2). Of the $13 \mathrm{My}^{-}$ mutants, three were feeble mycobacillin producers and the remaining ten were non-producers as tested by thin-layer chromatography. The $\mathrm{My}^{-}$character of these ten mutants was finally confirmed by testing their inability to produce ${ }^{14} \mathrm{C}$-labelled mycobacillin in the cell-free system. There was negligible incorporation of radioactivity into mycobacillin by these ten mutants as compared with that by the wild-type (Table 1).

All the $13 \mathrm{My}^{-}$mutants were $\mathrm{Spo}^{+}$. Four of them (N-20, N-14, N-4 and N-6) were originally $\mathrm{Spo}^{-}$but they spontaneously reverted to $\mathrm{Spo}^{+}$, while still retaining their $\mathrm{My}^{-}$character. The degree of sporulation of these $\mathrm{My}^{-}$mutants was similar to that of the wild-type Bacillus subtilis $\mathrm{B}_{3}$ (Table 1).

Amino acid composition, $C$ - and $N$-terminal amino acid residue and molecular weight of peptides accumulating in the blocked mutants. Culture supernatants from the wild-type mycobacillin producer strain Bacillus subtilis $\mathrm{B}_{3}$, three feeble antibiotic producer mutants $\left(\mathrm{N}-3^{\prime} 05, \mathrm{~N}^{\prime}-2^{\prime} 01\right.$ and $\left.\mathrm{N}-3^{\prime} 01\right)$ and also three strictly $\mathrm{My}^{-}$mutants ( $\mathrm{N}-54, \mathrm{~N}-20$ and $\left.\mathrm{N}-6\right)$ contained no ninhydrin-positive material other than aspartic acid and glutamic acid as used initially in the fermentation broth. Culture supernatants from the remaining seven strictly $\mathrm{My}^{-}$mutants $(\mathrm{N}-10, \mathrm{~N}-9, \mathrm{~N}-14$, $\mathrm{N}-7, \mathrm{~N}-1111, \mathrm{~N}-16$ and $\mathrm{N}-4$ ) contained additional ninhydrin-positive materials. Four of them, $\mathrm{N}-10, \mathrm{~N}-4, \mathrm{~N}-14$ and $\mathrm{N}-16$, produced only a single peptide, designated MI, MII, MIII and MIV, respectively, whereas the remaining three produced two peptides each: MV and MVI by N-7, MVII and MVIII by N-1111, and MIX and MX by N-9 (Table 2). Peptides MI, MIV, MVIII and MX appeared to be identical as indicated by their $R_{F}$ values and amino acid composition. In the same way peptides MII, MIII and MV appeared to be identical as did peptides MVI, MVII and MIX. Hence, the mutants produced only three chemically different peptides; two contained proline whereas the other one (MVI/MVII/MIX) did not. Of the two proline-containing peptides, the first one (MI/MIV/MVIII/MX) contained four mycobacillin amino acids whose molar proportions were the same as that of the equivalent segment of the mycobacillin molecule (see Fig. 1). The second peptide (MII/MIII/MV) contained eight amino acids of which five were 
Table 1. Characterization of auxotrophic and $M y^{-}$mutants of $B$. subtilis $B_{3}$

\begin{tabular}{|c|c|c|c|c|}
\hline \multirow[b]{2}{*}{ Strain } & \multicolumn{3}{|c|}{ Mycobacillin activity } & \multirow[b]{2}{*}{$\begin{array}{c}\text { Sporulation } \\
\text { frequency }+ \\
(\%)\end{array}$} \\
\hline & $\begin{array}{l}\text { Detection by } \\
\text { streak method* }\end{array}$ & $\begin{array}{c}\text { Extracellular } \dagger \\
{\left[\mu \mathrm{g}(\mathrm{ml} \text { broth })^{-1}\right]}\end{array}$ & $\begin{array}{c}\text { Radioactivity } \\
\text { incorporated during } \\
\text { cell-free } \\
\text { synthesis (c.p.m.) }\end{array}$ & \\
\hline$B_{3}$ (wild-type) & + & 352 & 4512 & 24 \\
\hline A-1 & + & 350 & 4500 & 25 \\
\hline$A-1^{\prime}$ & + & 350 & 4514 & 25 \\
\hline$A-3$ & + & 352 & 3995 & 25 \\
\hline A-4 & + & 348 & 4506 & 26 \\
\hline A-5 & + & 348 & 4500 & 20 \\
\hline $\mathrm{N}-2^{\prime} 01$ & + & 46 & 580 & 23 \\
\hline $\mathrm{N}-3^{\prime} 01$ & + & 45 & 582 & 26 \\
\hline $\mathrm{N}-3^{\prime} 05$ & + & 45 & 578 & 21 \\
\hline $\mathrm{N}-20$ & - & ND & 65 & 23 \\
\hline $\mathrm{N}-14$ & - & ND & 88 & 23 \\
\hline$N-4$ & - & ND & 67 & 24 \\
\hline$N-6$ & - & ND & 48 & 23 \\
\hline$N-54$ & - & ND & 27 & 23 \\
\hline $\mathrm{N}-9$ & - & ND & 52 & 26 \\
\hline $\mathrm{N}-16$ & - & ND & 55 & 25 \\
\hline N-7 & - & ND & 78 & 26 \\
\hline $\mathrm{N}-10$ & - & ND & 45 & 22 \\
\hline N-1111 & - & ND & 72 & 21 \\
\hline
\end{tabular}

* + , Antibiotic producer; - , antibiotic non-producer.

$\dagger$ Antibiotic was assayed by the cup-plate method. ND, Not detectable (detection limit $40 \mu \mathrm{g} \mathrm{ml}^{-1}$ ).

$\ddagger$ Spore counts (determined at $48 \mathrm{~h}$ ) are expressed as a percentage of the viable count at the end of exponential growth.

mycobacillin amino acids and three (glycine, valine and methionine) were not. The third nonproline peptide (MVI/MVII/MIX) contained five amino acids of which four were present in mycobacillin and one (cysteine) was not.

The two proline-containing peptides contained proline as the $\mathrm{N}$-terminal and aspartic acid as the $\mathrm{C}$-terminal residue and the third peptide contained aspartic acid as the $\mathrm{N}$-terminal and cysteine as the $\mathrm{C}$-terminal residue (Table 2).

The molecular weights of peptides MI, MIV, MVIII and MX, elaborated by mutants $\mathrm{N}-10$, $\mathrm{N}-16, \mathrm{~N}-1111, \mathrm{~N}-9$, respectively, were found to be 640 by gel-filtration on Sephadex G-25 on the basis of migration rates relative to cytochrome $c$ of a series of calibration peptides (see Methods).

Amino acid sequence of the mycobacillin amino acid-containing peptide accumulating in the blocked mutants. The C-terminal amino acid of peptide MI/MIV/MVIII/MX was aspartic acid (Table 2). The three consecutive amino acids from the $\mathrm{N}$-terminus were $\mathrm{Pro} \rightarrow \mathrm{Asp} \rightarrow \mathrm{Glu}$. From the molar proportions of the constituent amino acids and the molecular weight of the peptide, the fourth amino acid from the $\mathrm{N}$-terminus was tyrosine. Hence the sequence of amino acids in peptide MI/MIV/MVIII/MX was $\mathrm{Pro} \rightarrow \mathrm{Asp} \rightarrow \mathrm{Glu} \rightarrow \mathrm{Tyr} \rightarrow \mathrm{Asp}$.

Isolation of peptides from the cell-free synthesizing system obtained from wild-type and blocked mutants. The cell-free synthesis of mycobacillin and related incomplete peptides was studied by using enzyme systems from the wild-type and blocked mutant strains. The full complement of amino acids present in mycobacillin and also in the three other peptides isolated from $\mathrm{My}^{-}$ mutants was present in the reaction mixture. The seven strictly $\mathrm{My}^{-}$mutants $(\mathrm{N}-14, \mathrm{~N}-4, \mathrm{~N}-9$, $\mathrm{N}-16, \mathrm{~N}-7, \mathrm{~N}-10$ and $\mathrm{N}-1111)$ synthesized only one peptide, which was the same as MI/MIV/MVIII/MX (Table 2). The feeble antibiotic producers (N-2'01, N-3'01 and N-3'05) and wild-type Bacillus subtilis $\mathbf{B}_{3}$ produced mycobacillin only. We also studied the other three strict $\mathrm{My}^{-}$mutants (N-20, N-6 and N-54). Although they did not accumulate any peptide in the 


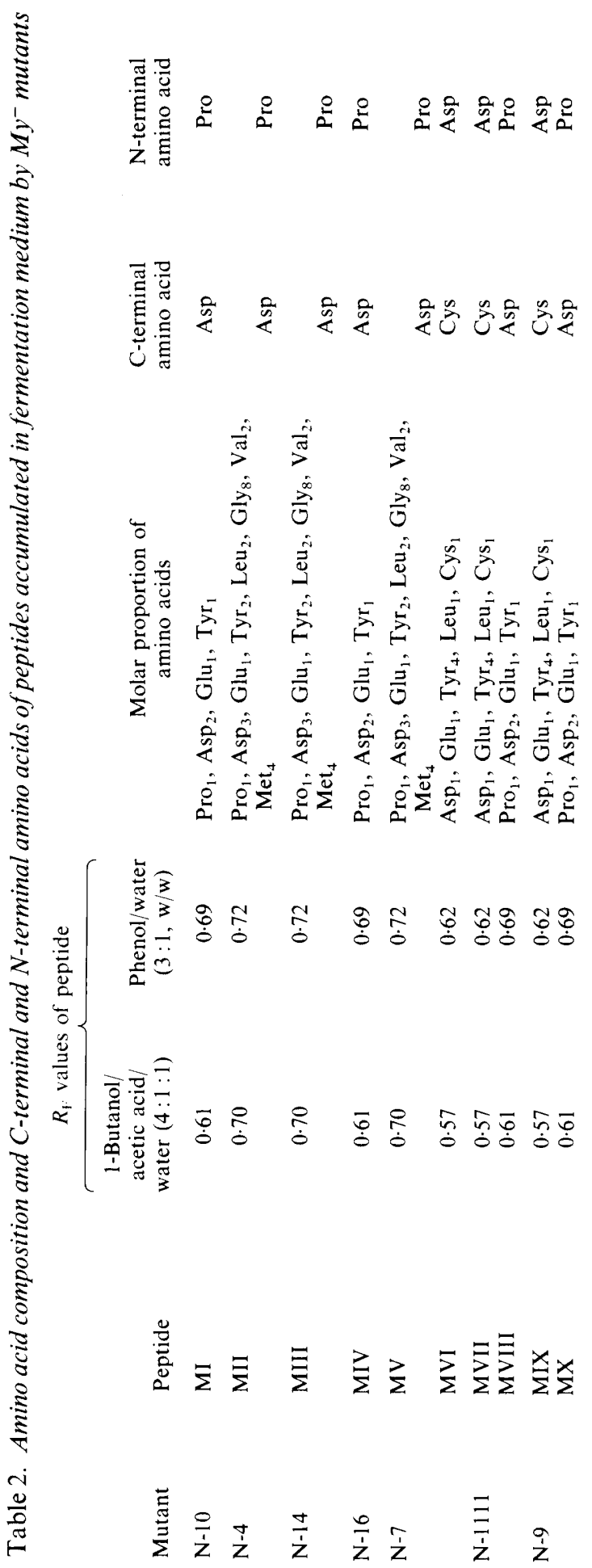


Table 3. Cell-free synthesis of mycobacillin by different combinations of the fractionated enzyme complex of wild-type and $\mathrm{My}^{-}$strains

A, B and C are three fractions of mycobacillin synthetase (Ghosh et al., 1983). M, Mutant (specified in column 1); W, wild type. The control value for $\mathrm{AW}+\mathrm{BW}+\mathrm{CW}$ was 3689 c.p.m.

Radioactivity incorporated into mycobacillin (c.p.m.)

\begin{tabular}{|c|c|c|c|c|c|c|c|}
\hline \multirow[b]{2}{*}{ Mutant } & \multicolumn{7}{|c|}{ Protein fractions used: } \\
\hline & $\begin{array}{c}\mathrm{AM}+\mathrm{BM} \\
+\mathrm{CM}\end{array}$ & $\begin{array}{c}A W+B M \\
+C M\end{array}$ & $\begin{array}{c}\mathrm{AM}+\mathrm{BW} \\
+\mathrm{CW}\end{array}$ & $\begin{array}{c}\mathrm{AW}+\mathrm{BW} \\
+\mathrm{CM}\end{array}$ & $\begin{array}{c}\mathrm{AM}+\mathrm{BM} \\
+\mathrm{CW}\end{array}$ & $\begin{array}{c}\mathrm{AW}+\mathrm{BM} \\
+\mathrm{CW}\end{array}$ & $\begin{array}{c}\mathrm{AM}+\mathrm{BW} \\
+\mathrm{CM}\end{array}$ \\
\hline $\mathrm{N}-10$ & 288 & 275 & 3222 & 3215 & 320 & 290 & 3115 \\
\hline $\mathrm{N}-16$ & 312 & 307 & 3162 & 3412 & 299 & 311 & 3182 \\
\hline$N-1111$ & 260 & 268 & 3704 & 3448 & 300 & 287 & 3402 \\
\hline N-9 & 322 & 332 & 3280 & 3125 & 302 & 318 & 2995 \\
\hline $\mathrm{N}-20$ & 270 & 258 & 3324 & 3403 & 280 & 287 & 3112 \\
\hline N-6 & 307 & 282 & 3422 & 3382 & 295 & 299 & 3000 \\
\hline $\mathrm{N}-54$ & 252 & 263 & 3504 & 3421 & 282 & 332 & 3117 \\
\hline$N-4$ & 327 & 309 & 3662 & 277 & 299 & 309 & 287 \\
\hline $\mathrm{N}-14$ & 302 & 326 & 3111 & 247 & 301 & 291 & 307 \\
\hline $\mathrm{N}-7$ & 245 & 279 & 3303 & 288 & 222 & 227 & 252 \\
\hline
\end{tabular}

culture supernatant, they synthesized the same peptide in the cell-free system as did the other seven $\mathrm{My}^{-}$mutants.

The peptide synthesized in the cell-free system contained four amino acids in the same molar proportion, and sequence, as found in the pentapeptide (MI/MIV/MVIII/MX) that accumulated in the culture broth of the mutant strains $\mathrm{N}-10, \mathrm{~N}-16, \mathrm{~N}-1111$ and $\mathrm{N}-9$ (Table 2).

In vitro synthesis of mycobacillin by reconstituted cell extracts. In a series of reconstitution experiments, cell-free extracts from wild-type and mutant bacteria were separated into fractions A, B and C as described by Ghosh et al. (1983). When these fractions from wild-type bacteria are combined, mycobacillin is synthesized from its constituent amino acids (Ghosh et al., 1983). The results of these experiments in which mutant and wild-type fractions were mixed in various combinations (Table 3 ) indicated that the seven mutants $\mathrm{N}-10, \mathrm{~N}-16, \mathrm{~N}-1111, \mathrm{~N}-9, \mathrm{~N}-20, \mathrm{~N}-6$ and $\mathrm{N}-54$ have a defect in enzyme fraction $\mathrm{B}$ and the other three $\mathrm{N}-4, \mathrm{~N}-14$ and $\mathrm{N}-7$ have a defect in both fractions $\mathrm{B}$ and $\mathrm{C}$.

\section{DISCUSSION}

In the study of the biosynthesis of mycobacillin we have isolated thirteen $\mathrm{My}^{-}$mutants from an auxotrophically tagged mycobacillin producer strain of $B$. subtilis $\mathbf{B}_{3}$. These mutants were all $\mathrm{Spo}^{+}$with the exception of four isolates which were originally $\mathrm{Spo}^{-}$but subsequently reverted spontaneously to $\mathrm{Spo}^{+}$. The degree of sporulation of all of these strains was similar to that of the wild-type. In a study on biosynthesis using genetically blocked strains it is essential to use structural gene mutants rather than pleiotropic regulatory ones. Studies of peptide accumulation were therefore undertaken with these mutants; these led to the isolation of three chemically different peptides whose amino acid composition and $\mathrm{N}$-terminal and $\mathrm{C}$-terminal residues were determined. Since our earlier studies had indicated that proline was the initiating amino acid for mycobacillin biosynthesis (Sengupta \& Bose, 1974), peptides lacking N-terminal proline and also those containing non-mycobacillin amino acids were considered unlikely to be intermediates in mycobacillin biosynthesis. There was only one pentapeptide (as determined by molecular weight) which contained not only four mycobacillin amino acids but also proline at the $\mathrm{N}$-terminus and aspartic acid as the $\mathrm{C}$-terminal amino acid. The formation of such a peptide could be visualized if mycobacillin synthesis started with proline and was blocked between aspartate and tyrosine (see Fig. 1), in which case the product should be a pentapeptide with a sequence equivalent to that of the corresponding region of the mycobacillin molecule. The amino acid sequence of this peptide entirely agreed with the prediction. 


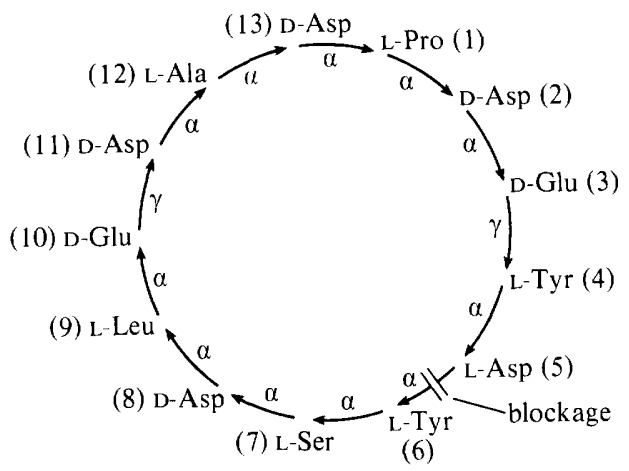

Fig. 1. Structure of mycobacillin. The arrows indicate peptide linkages, and the type of linkage ( $\alpha$ or $\gamma$ ) is shown.

Sengupta \& Bose (1972) reported that the enzyme system obtained from a wild-type producer strain gave rise to a hexapeptide when incubated in a cell-free system in the presence of the four amino acids that constitute the present pentapeptide. The limitation imposed in the earlier work was not in the enzyme system but in the availability of amino acids, whereas in the present case the limitation was in the enzyme system and not in the availability of amino acids, which resulted in the formation of a pentapeptide due to a genetic lesion as indicated in Fig. 1.

That the pentapeptide is an intermediate in the biosynthesis of mycobacillin was further confirmed by studies on cell-free synthesis using the blocked mutants. Extracts from the blocked mutants produced only one peptide in the cell-free system instead of the three peptides of different chain lengths that were observed in the case of whole-cell fermentation by the blocked mutants. The amino acid composition, molecular weight and sequence of this peptide showed it to be identical to the pentapeptide referred to above. The lack of peptide products other than the pentapeptide might be due to the use of a somewhat purified enzyme system from the blocked mutants. Thus the pentapeptide $\mathrm{Pro} \rightarrow \mathrm{Asp} \rightarrow \mathrm{Glu} \rightarrow \mathrm{Tyr} \rightarrow \mathrm{Asp}$ which accumulated both in the whole-cell culture supernatant and during in vitro synthesis with the blocked mutants might be considered an intermediate in the biosynthesis of mycobacillin.

Ghosh et al. (1983) successfully fractionated cell extracts to produce three fractions (A, B and C), all of which were necessary for the in vitro synthesis of mycobacillin from its constituent amino acids. To determine which of these fractions is defective in the $\mathrm{My}^{-}$mutants, fractions from wild-type and mutant strains were mixed in various combinations. Mutants $\mathrm{N}-10$ and $\mathrm{N}$ 16 , which produced only the above pentapeptide both in culture broth and in the cell-free system, have a defect in the enzyme fraction B. Mutants $\mathrm{N}-1111$ and $\mathrm{N}-9$, which produced the same pentapeptide and another peptide in the culture broth but only the pentapeptide in the cell-free system, also have a defect in the enzyme fraction B. Mutants N-20, N-6 and N-54, which did not produce any peptide in the culture broth but did produce the same pentapeptide as mentioned above in the cell-free system, also have a defect in the enzyme fraction B. Mutants N-4 and N-14 produced one peptide in the culture broth but produced the same pentapeptide in the cell-free system, and have defects in both enzyme fractions B and C. The remaining mutant, $\mathrm{N}-7$, which produced two peptides in the culture supernatant but produced the same pentapeptide in the cell-free system, also has a defect in both enzyme fractions B and C. All these mycobacillinnegative strains are therefore structural gene mutants.

The importance of the pentapeptide Pro $\rightarrow A s p \rightarrow G l u \rightarrow T y r \rightarrow A s p$ in the biosynthesis of mycobacillin is thus indicated.

The authors are grateful to Department of Science and Technology, Government of India, New Delhi for financial assistance. 


\section{REFERENCES}

Adelberg, E. A., Mandel, M. \& Cheinchingchen, G. (1965). Optimal conditions for mutagenesis by $N$ methyl- $N^{\prime}$-nitro- $N$-nitrosoguanidine in Escherichia coli $\mathbf{K}_{12}$. Biochemical and Biophysical Research Communications 18, 788-795.

Akabori, S., Ohno, K., Ikenaka, T., OKada, Y., Hanafusa, H., Haruna, I., Tsugita, A., Sugae, K. \& Matsushima, T. (1956). Hydrazinolysis of peptides and proteins. II. Fundamental studies on the determination of the carboxyl ends of proteins. Bulletin of the Chemical Society of Japan 29, 507.

BanerJee, A. B. \& Bose, S. K. (1964). A rapid method for isolating mutants of Bacillus subtilis producing increased or decreased amounts of the antibiotic, mycobacillin. Journal of Applied Bacteriology 27, 9395 .

Beadle, G. W. \& TATUM, E. L. (1941). Genetic control of biochemical reactions in Neurospora. Proceedings of the National Academy of Sciences of the United States of America 27, 499-506.

Carnegie, P. R. (1965). Estimation of molecular size of peptides by gel-filtration. Biochemical Journal 95, 9P.

Edman, P. (1960). Phenylthiohydantoins in protein analysis. Annals of the New York Academy of Sciences 88, 602-610.

EDMAN, P. \& BEGG, G. (1967). A protein sequenator. European Journal of Biochemistry 1, 80-91.

EDMAN, P. \& SJoQuisT, J. (1956). Identification and semiquantitative determination of 3-phenyl-2-thiohydantoins. Acta chemica scandinavica 10, 15071509.

Edwards, S. L. \& HolT, G. (1974). Mutants of Aspergillus nidulans impaired in penicillin biosynthesis. Journal of General Microbiology 84, 420422.

Fujisawa, Y., ShirafujiI, H., Kida, M., Nara, K., Yoweda, M. \& KanZaKi, T. (1973). Cephalosporin $\mathrm{C}$ biosynthesis. Nature New Biology 246, 154155.

Ghosh, S. K., Mukhopadhyay, N. K., Majumder, S. \& Bose, S. K. (1983). Fractionation of the mycobacillin synthesizing enzyme system. Biochemical Journal 215, 539-543.

GIRI, K. V., RADHAKRISHNA, A. N. \& BaIDYANATHAN, C. S. (1952). Some factors influencing the determination of amino acids separated by circular paper chromatography. Analytical Chemistry 24, 1677.

Goswami, S. K. \& Bose, S. K. (1982). Isolation of mycobacillin from the culture filtrate of a mutant derivative of Bacillus subtilis $\mathrm{B}_{3}$. Indian Journal of Biochemistry and Biophysics 19, 57-58.

Holliday, R. (1956). A new method for identification of biochemical mutants of microorganisms. Nature, London 178, 987.

LEDERBERG, J. (1950). Isolation and characterization of biochemical mutants of bacteria. Methods in Medical Research 3, 5.

Lemke, P. A. \& Nash, C. H. (1972). Mutations that affect antibiotic synthesis by Cephalosporium acremonium. Canadian Journal of Microbiology 18, 255 259.

LODER, P. B. \& ABRAHAM, E. P. (1971a). Isolation and nature of intracellular peptides from a cephalosporin
C producing Cephalosporium sp. Biochemical Journal 123, 471-476.

Loder, P. B. \& Abraham, E. P. (1971b). Biosynthesis of peptides containing $\alpha$-aminoadipic acid and cysteine in extracts of a Cephalosporium sp. Biochemical Journal 123, 477-482.

MaJumder, S. K. \& Bose, S. K. (1958). Mycobacillin, a new antifungal antibiotic produced by Bacillus subtilis. Nature, London 181, 134-135.

MaJumder, S. K. \& Bose, S. K. (1960a). Isolation and homogeneity of mycobacillin. Archives of Biochemistry and Biophysics 90, 154-158.

Majumder, S. K. \& Bose, S. K. (1960b). Trace element requirements of Bacillus subtilis for mycobacillin formation. Journal of Bacteriology 79, 565-565.

McCormick, J. R. D., John, P. M., Newell, A. G., AlberG, O. S. \& DoerschuK, P. (1958). Two new tetracycline-related compounds: 7-chloro-5a(11a)dehydrotetracycline and 5a-epi-tetracycline. A new route to tetracycline. Journal of the American Chemical Society 80, 5572-5573.

McCormick, J. R. D., Jensen, E. R., ARnold, N. H., Corey, H. S., JoAChim, U. H., JohnSon, S., Miller, P. \& SJolander, N. (1968). Biosynthesis of tetracyclines. XI. The methylanthrone analog of protetrone. Journal of the American Chemical Society 90, 7127.

Mukherjee, P. K. \& Paulus, H. (1977). Biological function of gramicidin: studies on gramicidin negative mutants. Proceedings of the National Academy of Sciences of the United States of America 74, 780-784.

Mukhopadhyay, N. K., Majumder, S., Ghosh, S. K., Bhattachar Ya, D. \& Bose, S. K. (1984). Standardisation of parameters for the mycobacillin synthetase activity. Folia microbiologica 29, (in the Press).

QueEner, S. W., Capone, J. J. \& Nagarajan, R. (1974). Synthesis of deacetoxycephalosporin C by a mutant of Cephalosporium acremonium. Antimicrobial Agents and Chemotherapy 6, 334-337.

RAETZ, C. R. H. (1975). Isolation of Escherichia coli mutants defective in enzymes of membrane. Proceedings of the National Academy of Sciences of the United States of America 72, 2274-2278.

SANGER, F. (1945). The free amino groups of insulin. Biochemical Journal 39, 507-515.

Sengupta, S. \& Bose, S. K. (1971). Properties and localisation of mycobacillin-synthesizing enzyme system in Bacillus subtilis $\mathbf{B}_{3}$. Biochimica et biophysica acta 237, 120-122.

Sengupta, S. \& Bose, S. K. (1972). Peptides from a mycobacillin synthesizing cell-free system. Biochemical Journal 128, 47-52.

Sengupta, S. \& Bose, S. K. (1974). A prolinedependent ATP-32 $\mathrm{P}_{\mathrm{i}}$ exchange in Bacillus subtilis $\mathrm{B}_{3}$ producing mycobacillin. Indian Journal of Biochemistry and Biophysics 11, 335-336.

Sengupta, S. \& Bose, S. K. (1982). Role of peptides from mycobacillin synthesizing system in biosynthesis of mycobacillin. In Peptide Antibiotics: Biosynthesis and Functions, pp. 109-113. Edited by $\mathrm{H}$. Kleinkauf \& H. von Dohren. Berlin: Walter de Gruyter.

SJOQUIST, J. (1953). Paper-strip identification of phenylthiohydantoins. Acta chemica scandinavica 7 , 447-448. 